\title{
Bank Bankruptcy in Canada: A Comparative Perspective
}

Stephanie Ben-Ishai

Osgoode Hall Law School of York University, sbenishai@osgoode.yorku.ca

Source Publication:

Banking and Finance Law Review. Volume 24, Number 3 (2008), p. 59.

Follow this and additional works at: https://digitalcommons.osgoode.yorku.ca/scholarly_works

Part of the Banking and Finance Law Commons

(c) $(1) \Theta(9$

This work is licensed under a Creative Commons Attribution-Noncommercial-No Derivative Works 4.0 License.

\section{Recommended Citation}

Ben-Ishai, Stephanie. "Bank Bankruptcy in Canada: A Comparative Perspective." Banking and Finance Law Review 24.3 (2008): 59.

This Article is brought to you for free and open access by the Faculty Scholarship at Osgoode Digital Commons. It has been accepted for inclusion in Articles \& Book Chapters by an authorized administrator of Osgoode Digital Commons. 


\title{
Bank Bankruptcy in Canada: A Comparative Perspective
}

\author{
Stephanie Ben-Ishai*
}

\section{INTRODUCTION}

During the Great Depression (1930-1933), over 9,000 banks failed in the United States, while not a single bank failed in Canada. ${ }^{1}$ In fact, there have been relatively few instances of bank bankruptcy proceedings in Canada from 1867 to present. Approximately eleven bank bankruptcies have been referenced in the case law to date. The first bank bankruptcy appears to be the Bank of Prince Edward Island (1882). ${ }^{2}$ Next came the Exchange Bank of Canada (1883), ${ }^{3}$ followed by the Maritime Bank (1887), ${ }^{4}$ the Central Bank of Canada (1887), ${ }^{5}$ La Banque Ville

* Associate Professor, Osgoode Hall Law School, York University, Toronto, Canada, INSOL International Scholar 2008-9. This article was originally prepared as part of the INSOL International Scholar requirements. Thanks to Benjamin Geva and Neil Connolly for helpful comments and suggestions that improved this article and to Virginia Torrie for research assistance. All errors and views are my own. Research for this article is current to March 13, 2009.

1 Chris C. Nicholls, Financial Institutions: The Regulatory Framework (Toronto: LexisNexis, 2008) at 16. This fact can be explained in part by the different landscape of the Canadian financial sector. In particular, there are a number of non-bank deposit-taking institutions that fall under provincial jurisdiction and have failed spectacularly.

2 R. v. Bank of Nova Scotia (1885), 1885 CarswellPEI 1, 4 Cart. B.N.A. 391, 11 S.C.R. 1 (S.C.C.). "The said Bank of Prince Edward Island became insolvent, and, on the nineteenth day of June, A.D. 1882, an order was made by the Hon. James Horsfield Peters, one of the judges of the Supreme Court of Prince Edward Island, for the winding up of the said bank, under the provisions of the Act, 45 Vic., ch. 23, entitled: "An Act Respecting Insolvent Banks, Insurance Companies, Loan Companies, Building Societies and Trading Corporations."'”

3 Exchange Bank v. Stinson (1885), 8 O.R. 667 (Ont. H.C.) at paras. 2-3, the Exchange Bank of Canada was "adjudged insolvent under the provisions of 45 Vic. c. 23, D., and an order had been made by the Superior Court of the Province of Quebec for the winding up of its affairs. ..."

4 Maritime Bank v. Troop (1888), 27 N.B.R. 295, 1888 CarswellNB 38 (N.B. C.A.) at para. 2; reversed on other grounds (1889), 1889 CarswellNB 77, 16 S.C.R. 456 (S.C.C.). Maritime Bank was suspended and entered into winding-up proceedings in March 1887, under the Winding-up Act, R.S.C. 1886, c. 129 [Winding-up Act, 1886].

5 Central Bank, Re (1888), 15 O.R. 625 (Ont. H.C.) at para. 5. On December 3, 1887, the Central Bank of Canada became subject to a winding-up order under the Winding-up Act, 1886. 
Marie (1899), ${ }^{6}$ the Farmers Bank of Canada $(1910),{ }^{7}$ the Monarch Bank of Canada (1910), ${ }^{8}$ Ontario Bank (1910), ${ }^{9}$ the Sovereign Bank of Canada (1911), ${ }^{10}$ the Bank of Vancouver (1916) ${ }^{11}$ and the Home Bank of Canada (1923). ${ }^{12}$

It would be another four decades before the next bank bankruptcy took place in 1967, when the Bank of Western Canada was wound up. ${ }^{13}$ The few Canadian banks that suffered financial difficulties through the Great Depression, World War II and its aftermath were absorbed into larger banks without creating significant difficulties for their creditors or depositors. Two decades later, Northland Bank

6 Kent v. Munroe (1904), 1904 CarswellOnt 733, 4 O.W.R. 468, 8 O.L.R. 723 (Ont. C.P.). The notice of presentation of the petition to wind up the bank [under the Winding-up Act, 1886] was given on August 9, and the winding-up order was made on August 10, 1899.

$7 \quad$ Farmers Bank, Re (1916), 35 O.L.R. 470, 28 D.L.R. 328 (Ont. H.C.) at para. 3. The Farmers Bank of Canada became subject to a winding-up order under the provisions of the Winding-up Act, R.S.C. 1906, ch. 144 on January 25, 1911.

8 Monarch Bank, Re (1910), [1910] 22 O.L.R. 516, 1910 CarswellOnt 628, 17 O.W.R. 901 (Ont. H.C.) at para. 1; leave to appeal allowed (1911), 1911 CarswellOnt 170, 18 O.W.R. 743, 2 O.W.N. 738 (Ont. C.A.). The Monarch Bank of Canada was referred for winding-up under the Dominion Winding-up Act.

9 Ontario Bank (Re) (1910), 21 O.L.R. 1, O.J. No. 100 (C.A.) at para. 1. "By an order made by a Judge of the High Court, in Chambers, on the 29th September, 1908, upon a petition by the Bank of Montreal and another, creditors of the Ontario Bank, it was declared that the Ontario Bank was an incorporated bank and was insolvent, within the meaning of the Dominion Winding-up Act and amendments thereto, and it was ordered that the business of the bank and the bank should be wound up under the provisions of the Act and amendments."

10 Sovereign Bank, Re (1915), 27 D.L.R. 760, 34 O.L.R. 577 (Ont. H.C.) at paras. 1, 3. Sovereign Bank of Canada became insolvent and a winding-up order was issued by the court on May 1, 1911.

11 It is unclear exactly when the Bank of Vancouver entered winding-up proceedings. It was sometime (probably fairly recently) before the following case was brought in 1916: Bank of Vancouver, Re (1916), 1916 CarswellBC 118, [1917] 1 W.W.R. 163 (B.C. S.C. [In Chambers]) ("the liquidator of the Bank of Vancouver applies to vary the certificate of the Registrar").

12 Home Bank of Canada, Re, [1923] 4 D.L.R. 891, 54 O.L.R. 606 (Ont. H.C.) (petitions an order for the winding-up of the Home Bank of Canada). Upon several petitions for the winding-up of a chartered bank, under the Winding-up Act, R.S.C. 1906, ch. 144 [Winding-up Act, 1906], and a written acknowledgment based on a resolution passed by the directors admitting insolvency, the court granted an order declaring the Home Bank of Canada insolvent on October 24, 1923.

13 Bank of Western Canada v. Canada Finance \& Investments Ltd. (1967), [1967] M.J. No. 62, 1967 CarswellMan 61, 62 W.W.R. 137, 65 D.L.R. (2d) 381 (Man. C.A.). The Bank of Western Canada was wound up under the Winding-Up Act, 1886 at the request of the majority of its shareholders (reasons for the shareholders' decision were not disclosed to the court). This was the first solvent bank to undergo winding-up proceedings, and the Manitoba court of appeal that held winding-up proceedings under WURA were equally open to solvent banks that received court approval. 
$(1985)^{14}$ was wound up, followed by the Canadian Commercial Bank (1985). ${ }^{15}$ The liquidation of both banks took over a decade to complete. Following the bankruptcies of these Western Canadian banks, Justice William Z. Estey led a commission examining the collapse of the Canadian Commercial Bank and Northland Bank (the "Estey Report"). ${ }^{16}$ In this 1986 report, the Commission described a set of circumstances involving severe corporate governance failures and a set of improvident lending procedures not unlike the current situation in the United States. ${ }^{17}$ Following the Estey Report, a number of changes were made to the regulatory framework for supervising banks in Canada (detailed in Part 4(b) below). The most recent Canadian bank bankruptcy was the Bank of Credit and Commerce International in $1991 .{ }^{18}$

This article provides an overview of the legal regime for bank bankruptcy in Canada. ${ }^{19}$ The Global Bank Insolvency Initiative: Legal, Institutional, and Regulatory Framework to Deal with Insolvent Banks ("GBI") ${ }^{20}$ is used as the framework for locating the Canadian system within an international context. Surprisingly little has been written about bank bankruptcies in North America, with much of the academic focus on developing countries. An obvious explanation for this is that in North America governments do not let banks (or at least major banks) fail. Even if this explanation is accurate, government solutions will often be in the shadow of the formal options for bank failure. Accordingly, an understanding of these options is crucial to comprehending and predicting government action in this regard. An

14 Northland Bank, Re, 1994 CarswellMan 14, [1994] 5 W.W.R. 610, (sub nom. Alberta v. Northland Bank) 93 Man. R. (2d) 138, 25 C.B.R. (3d) 166 (Man. Q.B.) at paras. 1-2. On January 20, 1986, a liquidator was appointed by this court (Manitoba Court of Queen's Bench), with such appointment deemed to be effective September 4, 1985, along with an order also to wind-up the Northland Bank.

A series of decisions are reported in relation to the winding-up of Canadian Commercial Bank. For example, Canada Deposit Insurance Corp. v. Canadian Commercial Bank, 1989 CarswellAlta 353, [1989] A.J. No. 561, 68 Alta. L.R. (2d) 194, 61 D.L.R. (4th) 161, (sub nom. Canadian Commercial Bank (In Liquidation), Re) 98 A.R. 353, 76 C.B.R. (N.S.) 1, [1989] 6 W.W.R. 154 (Alta. C.A.); leave to appeal allowed (1989), 101 A.R. 160 (note), 102 A.R. 80 (note), 70 Alta. L.R. (2d) lii, 65 D.L.R. (4th) vii (S.C.C.) [Re. Can. Commercial Bank].

16 The Honourable William Z. Estey, Report of the Inquiry into the Collapse of the CCB and Northland Bank (Ottawa: Supply and Services, 1986).

17 Ibid.

18 Eva H.G. Hüpkes, The Legal Aspects of Bank Insolvency (The Hague: Kluwer Law International, 2000) at 139. Although the insolvency proceedings were conducted in the United Kingdom and Luxemburg there were a few Canadian decisions, such as Bank of Credit \& Commerce International S.A. v. Haque (1996), 1996 CarswellOnt 2857, 13 O.T.C. 386, 42 C.B.R. (3d) 95, 30 O.R. (3d) 477 (Ont. Gen. Div.).

19 It is acknowledged that the Canadian system allows for significant pre-bankruptcy regulatory intervention; however, that is not the focus of this article.

20 Global Bank Insolvency Initiative, "Legal, Institutional, and Regulatory Framework to Deal with Insolvent Banks" (2003, in draft form) [GBI]. 
analogy may be drawn to the government bail out of the automobile industry which was set into motion in 2008 and was described as "orderly bankruptcy." 21

The balance of this article proceeds as follows. Part 2 provides a brief overview of the landscape and role of banks in Canada. Part 3 introduces the GBI. Part 4 offers an overview of the legal and institutional framework for bank bankruptcy in Canada. Part 5 describes and assesses the framework for liquidation proceedings under the Winding-up and Restructuring Act ("WURA"). ${ }^{22}$ Part 6 concludes and summarizes the assessment of the Canadian regime for bank bankruptcy by placing it in an international context.

\section{LANDSCAPE AND ROLE OF CANADIAN BANKS}

The United States is in the process of reforming the governance structure of banks in response to the 2008 global credit crisis; this may fuel similar reforms in Canada. However, the unique and pervasive role that Canadian banks have played within the Canadian economy and capital markets will undoubtedly continue. This role has been described as:

i. Taking the large majority of deposits from Canadians, safeguarding their savings for retirement, and financing the purchases of homes and cars, while also assisting businesses to meet their payrolls, buy inventory and expand their operations;

ii. Playing a pivotal role in providing financing to small and mediumsized enterprises;

iii. Supporting innovation and growth in Canada;

iv. Providing economic infrastructure in rural regions of Canada; and

v. Playing a significant role in our domestic bond and equity markets. ${ }^{23}$

Canada's banking market is more concentrated than other developed countries, including the United States. ${ }^{24}$ However, while Canada's six largest Canadian banks account for 89 per cent of Canada's domestic assets, they are not large by

21 See, for example, "Bus considering "orderly" auto bankruptcy" The Globe and Mail (18 December 2008), online: <http://www.theglobeandmail.com/servlet/story/ RTGAM.20081218.wbushautos1218/BNStory/Business>; ““'Orderly” bankruptcy considered for US carmakers" The Calgary Herald (18 December 2008), online: <http://www.calgaryherald.com/Orderly+bankruptcy+considered+carmakers/1092334/ story html $>$.

22 Winding-up and Restructuring Act, R.S.C. 1985, c. W-11 [WURA].

23 Government of Canada, "Response of the Government to Large Bank Mergers in Canada: Safeguarding the Public Interest for Canadians and Canadian Businesses and Competition in the Public Interest: Large Bank Mergers in Canada" (23 June 2003), online: <http://74.125.47.132/search?q=cache:iEF--5q1KcUJ:www.fin.gc.ca/activty/ pubs/mergers_e.pdf+bank+concentration+in+canada\&hl=en\&ct=clnk\&cd=2\&gl=ca> [Bank Mergers]. See also Nicholls, supra, n. 1 at 13-14.

24 Nicholls, ibid., at 19. Canada has fewer than 1 per cent of the number of banks in the United States. 
global standards. ${ }^{25}$ Rather, the five largest Canadian banks account for approximately 65 per cent of retail deposits, with credit unions and caisses populaires mainly accounting for the remaining deposits. ${ }^{26}$ Such second-tier institutions are more active in Western Canada and Quebec. ${ }^{27}$ Foreign banks may operate directly in Canada through a branch of the parent bank or through a Canadian subsidiary. ${ }^{28}$ Where a foreign bank operates through a branch of a foreign institution, it is prohibited from taking deposits of less than $\$ 150,000 .^{29}$

The current Canadian bank landscape can be roughly described as follows:

- 6 large banks;

- 12 smaller domestic chartered banks;

- 40 foreign-owned banks (as subsidiaries or foreign branches); and

- 1300 credit unions and caisses populaires. ${ }^{30}$

\section{GLOBAL BANK INSOLVENCY INITIATIVE}

The GBI was launched in 2002 by the World Bank and the International Monetary Fund working in conjunction with the Bank for International Settlements and the Financial Stability Forum. ${ }^{31}$ The GBI seeks to identify the appropriate legal, institutional and regulatory framework for addressing cases of bank insolvency and to progressively build an international consensus towards the acceptance of this framework. ${ }^{32}$ In addition, it provides guidance for the evaluation of a country's bank insolvency regime. ${ }^{33}$

To date, the limited academic and law reform work centered on improving the statutory regime for Canadian bank bankruptcies has focused on comparing the statutes and procedures for corporate bankruptcies to the statutes and procedures for bank bankruptcies. ${ }^{34}$ While this analysis is useful, it is internally focused and often more appropriate for analyzing how broadly the specific scheme for liquidating financial institutions should apply and whether it is appropriate for institutions

25 Ibid., at 19. For example, Canada's largest bank, the Royal Bank of Canada, ranked 37th in the world by assets in August, 2007 with 607.6 billion.

26 Ibid., at 18.

27 Ibid.

28 Ibid., at 26.

29 Ibid.

30 Canadian Bankers Association, "Canadian Bankers Association Submission in Response to Finance Canada's Large Bank Mergers in Canada: Competition in the Canadian Small and Medium-Sized Business Financing Market" (December 2003), online: <http://www fin.gc.ca/consultresp/mergersRespns_7-eng.asp>. GBI, supra, n. 20 at 4.

Ibid.

Ibid.

34 The most recent leading example of this scholarship is: Thomas G.W. Telfer \& Bruce Welling, "The Winding-Up and Restructuring Act: Realigning Insolvency's Orphan to the Modern Law Reform Process" (2008) 24 B.F.L.R. 233 at 233. 
other than banks, such as insurance companies. Given that there are so few bank bankruptcies in Canada and the statutory framework for bank bankruptcies may have broader normative implications, an international comparison complements the comparative scholarship on bank bankruptcies versus corporate bankruptcies written to date. Accordingly, for the purposes of this article, the latest GBI report, produced by staff from the World Bank and the International Monetary Fund from January 2002 to July 2003 following a board consultative process, is used as a framework to describe and assess the current Canadian regime for bank bankruptcies.

\section{LEGAL AND INSTITUTIONAL FRAMEWORK FOR BANK BANKRUPTCY IN CANADA}

It is widely accepted that banks have distinct characteristics that justify a separate bankruptcy regime, allowing greater regulator intervention. ${ }^{35}$ As we have seen over the last two years, the failure of financial institutions can have broad systemic effects. The possible detrimental macroeconomic effects triggered by the failure of one financial institution are used to justify the significant role of regulators in the bankruptcy of financial institutions. ${ }^{36}$ Further, because of the nature of banks, with a preponderance of small, unknowledgeable creditors, there is greater systemic risk than with other institutions. Based on these factors, in most jurisdictions bank bankruptcy is dealt with either by separate legislation from corporate bankruptcy or within the same legislative framework with modifications.

\section{(a) Bank Bankruptcy versus Corporate Bankruptcy}

In Canada, winding-up proceedings under the WURA is the only bankruptcy option for insolvent banks. There are a number of differences between the WURA and the Bankruptcy and Insolvency Act ("BIA"). ${ }^{37}$ First, though it has been suggested that the WURA has the potential to be used as a statutory restructuring instrument based on the historical use of its provisions (largely copied from a United Kingdom statute), there is no evidence of Canadian courts interpreting and applying these provisions in such a manner. ${ }^{38}$ Second, winding-up proceedings under

35 See, for example, David A. Skeel, Jr., "The Law and Finance of Bank and Insurance Insolvency Regulation," (1998) 76 Tex. L. Rev. 723, 774-76.

36 See Nicholls, supra, n. 1 at 2: "The principle goal of banking regulation, after all, is to ensure the "safety and soundness of banks." That goal often translates into ensuring that banks have a considerable source of financial capital, and are - implicitly or explicitly - protected by government resources from the possibility of business failure to which other non-financial commercial enterprises are always at risk."

Bankruptcy and Insolvency Act, R.S.C. 1985, c. B-3 [BIA].

38 Bradley Crawford, "Restructuring Financial Institutions under the Winding-Up Act" (1995) 10 B.F.L.R. 87 at 88-89 (this article asserts that ss. 65-66 of the WUA [now ss. 65-66 WURA], though unused in Canada for nearly 100 years, could sanction courtsupervised arrangements with creditors of financial institutions. The argument is premised on and the fact that ss. 65-66 WUA are derived from the English Joint Stock Companies Arrangement Act, 1870, which used these provisions for this purpose, in 
WURA (and its predecessor act, the $W U A^{39}$ ) can be quite lengthy due to the sheer complexity and enormity of bank liquidation, for which some proceedings have spanned over ten years. ${ }^{40}$ Third, the antecedent transaction rules or avoidance rules are different and arguably more complex and arcane than those found in the BIA. Fourth, WURA proceedings are largely court driven with, the liquidator taking on a much more significant role than the trustee in bankruptcy does under the BIA. Finally, it is important to note that the majority of the 2008 reforms to the $B I A$ and the Companies Creditors' Arrangement Act ("CCAA") ${ }^{41}$ have not resulted in corresponding reforms to the WURA.42

\section{(b) Bank Supervision}

Canadian banks are subject to the federal Bank $A c t^{43}$ and associated regulations, under which the Canadian federal government, through the Office of the Superintendent of Financial Institutions ("OSFI") oversees all federally regulated financial institutions. ${ }^{44}$ Noteworthy features of the Canadian bank regulatory system include: an early intervention system for troubled financial institutions; a risk-based

particular in Port Hood Coal Co., Re (1906), 1 E.L.R. 81, 1906 CarswellNS 22 (N.S. T.D.). This article cited no Canadian cases that had adopted such an approach and I have been unable to locate any Canadian cases subsequent to this article that have adopted this approach.

Winding Up Act, R.S.C. 1985, Chap. W-11 [Winding-Up Act, 1985].

40 See, for example, Scarth v. Northland Bank (Liquidator of) (1997), 139 W.A.C. 107, 115 Man. R. (2d) 107, [1997] M.J. No. 66, 1997 CarswellMan 40 (Man. C.A.); and Canada Deposit Insurance Corp. v. Canadian Commercial Bank, 269 A.R. 49, 2000 CarswellAlta 641, 2000 ABQB 440, [2000] A.J. No. 765, 82 Alta. L.R. (3d) 382, [2000] 9 W.W.R. 472, 34 C.E.L.R. (N.S.) 127 (Alta. Q.B.), in which the courts were deciding issues involved with the winding-up proceedings 12 and 15 years (respectively) after the initial winding-up order was given.

41 Companies' Creditors Arrangement Act, R.S.C. 1985, c. C-36 [CCAA].

42 Stephanie Ben-Ishai, Bankruptcy Reforms 2008 (Toronto: Carswell, 2008) at 79. Canada went through a major bankruptcy reform process beginning in 2003. The process is still ongoing. The majority of the reforms can be found in An Act to Amend the Bankruptcy and Insolvency Act, the Companies' Creditors Arrangement Act, the Wage Earner Protection Program Act and Chapter 47 of the Statues of Canada, 2005, 1st Sess., 39th Parl., 2007 and Bill C-12, An Act to amend the Bankruptcy and Insolvency Act, the Companies' Creditors Arrangement Act, the Wage Earner Protection Program Act and chapter 47 of the Statutes of Canada, 2005, 2nd Sess., 39th Parl., 2007. Following its enactment Bill C-12 became Chapter 36. A few provisions of Chapter 36 are already in force and it remains uncertain when the remainder will come into force. For the purpose of this article, these reforms are referred to as the "2008 reforms." The most recent reforms to the WURA came from the Budget Implementation Act, 2007, S.C. (2007), c. 29. For the purpose of this article, these reforms are referred to as the "2007 Reforms."

43 Bank Act, S.C. (1991), c. 46.

44 Office of the Superintendent of Financial Institutions Act, R.S.C. 1985, c.18 (3d. Supp). See also, Department of Finance Canada, "Canada's Banks" (August 2002), online: <http://www fin.gc.ca/toce/2002/bank_e html> [Canada's Banks]. 
supervisory framework; the Large Value Transfer System ("LVTS"), which provides settlement certainty for payments; and, the Canada Deposit Insurance Corporation ("CDIC"), which provides deposit insurance to depositors. ${ }^{45}$ The WURA is the only insolvency statute that applies "to incorporate banks and savings banks, [and] to authorized foreign banks." $" 46$ Both the BIA and CCAA specifically exclude banks from their application. ${ }^{47}$ For the WURA to apply to a financial institution, the institution must be "under the control, or [have] its assets are under the control, of the Superintendent and [be] the subject of an application for a winding-up order under section 10.1." 48

The Bank Act provides for an insolvent bank being wound up under the WURA. ${ }^{49}$ Section 340 of the Bank Act states that, where a bank is found to be insolvent within the meaning of the WURA the dissolution and liquidation proceedings under the Bank Act do not apply, and any such proceedings already commenced shall be stayed. ${ }^{50}$

The legal framework for bank insolvency in Canada essentially allows for the coexistence of proceedings administered by the banking supervisory authorities and judicial bankruptcy proceedings. The balance of this article will focus on the latter under the WURA.

\section{LIQUIDATION PROCEEDINGS UNDER THE WURA}

\section{(a) Termination of Banking Activities and Role of the Liquidator}

Under the WURA, the grounds for a winding-up application are that the bank is insolvent. The application may be made by the bank itself or by a creditor who is owed the sum of at least $\$ 200.51$ In most instances, where the debtor company is one to which the Canada Deposit Insurance Corporation Act ("CDICA") ${ }^{52}$ applies, the applicant is the CDIC or the Attorney General for Canada. ${ }^{53}$

An application for the winding-up of a bank must be made to the superior court in the province where the head office of the company is situated or, if there is no head office, in the province where the chief place of business of the company is conducted. ${ }^{54}$ Where a winding-up order is granted the bank must stop doing business, but its corporate status and powers continue until its affairs are wound up. ${ }^{55}$

45 Canada's Banks, ibid.

46 WURA, supra, n. 22, s. 6(1).

47 Jay A. Carfagnini, "Proceedings under the Winding-up Act (Canada)" (1988) 66 Can. Bankr. Rep. (N.S.) 77 at para. 13; see also, BIA, supra, n. 37, s. 2 "corporation," and CCAA, supra, n. 41, ss. 2 "company," 3(1).

48 WURA, supra, n. 22, ss. 6(1)(c), 10.1.

49 Carfagnini, supra, n. 47 at para. 18.

50 Bank Act, S.C. 1991 , c. 46, s. 340 [Bank Act].

51 WURA, supra, n. 22, s. 11.

52 Canada Deposit Insurance Corporation Act, R.S.C. 1985, c. C-3, s. 29 [CDICA].

53 Carfagnini, supra, n. 47 at para. 38.

54 WURA, supra, n. 22, s. 12(1).

55 Ibid., s. 19. 
The GBI provides that a liquidator should be able to assume control of the bank without delay and enjoy all legal powers necessary for preserving particular assets and protect the value of the estate as a whole. ${ }^{56}$ The WURA appears to meet the GBI's prescription on the role of the liquidator and her powers. The WURA gives the court the ability to appoint a liquidator who has the power to take into her custody and control all of the property, effects and choses in action to which the bank is entitled, or appears to be entitled. ${ }^{57} \mathrm{~A}$ liquidator, other than the CDIC, must be a licensed trustee in bankruptcy. ${ }^{58}$

Section 35 of the WURA lists a number of powers which a liquidator may exercise with the approval of the court, such as: bringing or defending actions or suits on behalf of the bank; carrying on the business of the bank; disposing of property and assets; and executing documents under the seal of the bank or otherwise. The WURA also contains a "catch-all" provision which permits the liquidator, with approval of the court, to "do and execute all such other things as are necessary for winding-up the affairs of the company and distributing its assets." ${ }^{59}$ In addition, the liquidator may, with the approval of the court, appoint a solicitor to assist in the liquidation. ${ }^{60}$ Finally, with the approval of the court, the liquidator may compromise all claims and debts of the bank. ${ }^{61}$

Within 120 days after her appointment the liquidator is required to prepare a statement of the assets, debts and liabilities of the bank and of the value of such assets as shown on the bank's books and records. ${ }^{62}$ After giving appropriate notice, the liquidator may distribute the assets of the bank as per the distribution scheme set out in the WURA and detailed in Part 5(d) below. ${ }^{63}$

The WURA provides little direction on the role that parties other than the court and the liquidator are to play in a liquidation. There is a statutory requirement to provide notice to the creditors, contributories, shareholders and members of a company before appointing a liquidator. ${ }^{64}$ However, in a number of recent cases, involving insurance companies, no permanent liquidator was appointed and the estate was liquidated by the provisional liquidator. ${ }^{65}$ This is similar to the issue that arose with interim receivers liquidating firms under the BIA. The 2008 amendments limit this possibility under the BIA by imposing time limits on interim receiverships and restoring them to an "interim status." 66

56

GBI, supra, n. 20 at 52.

WURA, supra, n. 22, s. 33.

Ibid., s. 23(2).

Ibid., s. 35(1)(h).

Ibid., s. 36.

Ibid., ss. 37-38.

Ibid., s. 34.

Ibid., s. 76; Carfagnini, supra, n. 47 at paras. 58, 60-64.

WURA, supra, n. 22, s. 26.

Telfer \& Welling, supra, n. 34.

BIA, supra, n. 37, ss. 47, 47.1, as am. by Wage Earner Protection Program Act [Not in force], S.C. (2005), c. 47, ss. 30(1), 30(2), 31(3), as am. by An Act to amend the BIA, the CCAA, the Wage Earner Protection Program Act and Chapter 47 of the Statutes of 
The GBI suggests that shareholders must be provided with a real opportunity to contest a bank's liquidation and that this form of participation is satisfied through a court-based process. However, the Canadian court-based process does not appear to follow this assumption. In 2000, the Insolvency Institute of Canada ("IIC") proposed a more significant role for inspectors as a way to provide for more stakeholder participation in the WURA liquidation process. ${ }^{67}$ Under the WURA, the court has the discretion to appoint one or more inspectors of the estate at any time the court deems such appointment advisable. ${ }^{68}$ The duty of the inspector is to assist and advise the liquidator in the liquidation of the company and to oversee the disposition of the assets at the best price. ${ }^{69}$ The IIC argued that inspectors were not fulfilling this role because the WURA does not provide sufficient details about the role of the parties other than court and the liquidator. ${ }^{70}$ The meaningful participation of other stakeholders, other than the court and the liquidator, continues to be a challenge under the WURA liquidation process.

\section{(b) Reviewable Pre-Bankruptcy Transactions}

Without articulating specific avoidance provisions for pre-bankruptcy transactions or dealings, the GBI makes clear that avoidance provisions should, on the one hand, respect the need for payment system finality and, on the other hand, give the liquidator the ability to apply to the courts so as to avoid certain transactions. ${ }^{71}$ The GBI suggests that certain transactions or transfers made by the bank in the specified period prior to the declaration of insolvency, that are deemed to be unfair or prejudicial to creditors, should be avoided, and property should be reclaimed. ${ }^{72}$

The WURA provides for avoidance provisions for fraudulent preferences and for fraudulent conveyances in sections 96 to 102 of the Act. The WURA avoidance provisions have been condemned because of their lack of clarity. The provisions continue to resemble 1875 legislation, which is unduly complicated and unclear. ${ }^{73}$ A further and related criticism is that the provisions are substantially different than the avoidance provisions under the $B I A .{ }^{74}$ In particular, two main critiques have been levelled against the treatment of fraudulent preferences under the WURA. First, the provisions retain an intention-based test focused on the creditor. Second, and inconsistent with the GBI suggestion, the liquidator has no time limitations on

Canada, 2005 [Not in force], S.C. 2007, c.36, ss. 14, 15. Interim receivership appointments expire automatically and are not to extend beyond specifically enumerated "interim" duties.

67 Insolvency Institute of Canada, The Winding Up and Restructuring Act: Recommendations for Reform: A Report of the Insolvency Institute of Canada (2000) at 21 [IIC].

WURA, supra, n. 22, s. 41.

69 Ibid., s. 41; Re Can. Commercial Bank, supra, n. 15 at 27.

70 IIC, supra, n. 67 at 21; see also, Telfer \& Welling, supra, n. 34 at 248-49.

71 GBI, supra, n. 20 at 58.

72 Ibid.

73 IIC, supra, n. 67 at 10; Telfer \& Welling supra, n. 34 at 244-47.

74 Ibid. 
how far back she can reach to avoid a fraudulent preference. ${ }^{75}$ Taken together, the fraudulent preference provisions in the WURA may contribute to uncertainty around the finality of transactions that can later be contested if the bank enters WURA proceedings.

The fraudulent conveyance provisions under the WURA are arguably less problematic than the fraudulent preference provisions. In particular, the treatment of one type of transaction under the WURA fraudulent conveyance provisions was clarified and harmonized with the BIA and the CCAA as part of the 2007 amendments. ${ }^{76}$ The 2007 amendments provide that a sale or transfer that takes place within 30 days of an insolvency will not be presumed to have been done in contemplation of insolvency and that the presumption of intent to prefer a creditor following a transfer, charge or payment made to a creditor does not apply in respect of a transfer, charge or payment made in connection with financial collateral and in accordance with the provisions of derivative contracts (referred to as Eligible Financial Contracts ("EFC") under Canadian bankruptcy legislation). ${ }^{77}$

In addition to antecedent transaction avoidance provisions, the GBI anticipates as part of her ability to review pre-bankruptcy transactions, the liquidator should have authority to terminate or continue executory contracts that will maximize the value of the estate. ${ }^{78}$ The WURA provides the liquidator with this ability. ${ }^{79}$ However, in the limited instances where the issue has been litigated, there has been some ambiguity surrounding the treatment of employment contracts. ${ }^{80}$ This is similar to the conflicting case law on the treatment of employment contracts prior to the 2008 amendments to the BIA. Issues that are not well settled under the WURA include the nature of employees' damages when a contract is terminated by the liquidator ${ }^{81}$ and whether the winding-up order operates as a notice of dismissal. ${ }^{82}$

\section{(c) Moratorium (Stay)}

The GBI states that it is generally accepted that the placement of a bank in liquidation must be accompanied by an automatic and immediate moratorium on

75 WURA, supra, n. 22, s. 99.

76 The amendments to the treatment of EFCS are the result of parallel amendments in the 2007 Federal Budget Budget Implementation Act, 2007 and Statute C-36, which provided that amendments would come from the first bill to be enacted. Accordingly, the 2007 reforms come from Bill C-52 [now the Budget Implementation Act, S.C. 2007, c. 29].

WURA, supra, n. 22, ss. 100(3) and 101(3).

GBI, supra, n. 20 at 56.

WURA, supra, n. 22, s. 35.

80 Bruce Harvey McPherson, The Law of Company Liquidations, 3rd ed. (Sydney: Law Book Co., 1987) at 149-50.

81 Ibid., at 150; Re R.S. Newman Ltd., [1916] 2 Ch. 309 (C.A.); Sovereign Bank v. Parsons (1912), 1912 CarswellOnt 770, [1913] A.C. 160, C.R. [1913] A.C. 259 at 293, 9 D.L.R. 476 (Ontario P.C.) [Sovereign Bank]; Rolfe v. Canadian Timber \& Saw Mills Ltd. (1906), 1906 CarswellBC 99, 12 B.C.R. 363 (B.C. C.A.).

82 Reference re Winding-Up Act (Canada) (1916), 1916 CarswellSask 168, 30 D.L.R. 574, [1917] 1 W.W.R. 135 (Sask. S.C. [In Chambers]); and Sovereign Bank, ibid. 
creditors' claims. ${ }^{83}$ This follows from the general justification for a moratorium in bankruptcy — preventing a race between creditors to seize assets and ensuring the orderly realization of assets and the equitable distribution of proceeds. However, the simple application of the rules that apply to a stay in a corporate bankruptcy are not sufficient to take into account the safety of payment and securities settlement systems and the smooth operation of financial markets. ${ }^{84}$

A number of specific issues are identified by the GBI with respect to bank bankruptcies. Two issues that are relevant in the Canadian context are:

1. The effect of a moratorium on depositors.

2. The treatment of mutual claims on the insolvency of one of the parties. ${ }^{85}$

The WURA provides for a stay of proceedings against a bank both before and after a winding-up order is granted. Rather than a complex set of technical rules, a significant amount of judicial discretion is provided, allowing the judiciary to impose the stay in a manner that maintains a smooth operation of financial markets. At any time after a petition for a winding-up order is presented, but before an order is made, the court may stay proceedings against the bank upon such terms as the court deems fit. ${ }^{86}$ After a winding-up order is made, no proceeding may be commenced or continued against the bank except by leave of the court and on such terms as the court imposes. ${ }^{87}$

The GBI's first issue regarding the impact of the moratorium on depositors is mitigated because Canada has a deposit insurance scheme in place. The second issue relating to the impact of the stay on set-off rights may be dealt with as a matter of judicial discretion under the WURA. However, the issue has recently been addressed with reforms to the definition and to the treatment of EFCs under the WURA. In this context, the issue centers on the fact that payment and securities settlement systems generally operate on a net-settlement basis where obligations of parties are discharged by set-off, and the balance owing is settled at the end of a period. Such contracts generally provide for set-off on an insolvency or default.

The 2007 amendments to the WURA introduced a broad definition for EFCs and recognize insolvency set-off, notwithstanding a stay of proceedings. ${ }^{88}$ In addition, realization of financial collateral securing obligations under EFCs is permitted, notwithstanding a stay of proceedings. ${ }^{89}$ These provisions were introduced as a result of significant pressure from the derivatives industry to bring the Canadian

GBI, supra, n. 20 at 56.

IIC, supra, n. 67 at 27.

GBI, supra, n. 20 at 57.

WURA, supra, n. 22, s. 17.

Ibid., s. 21.

Ibid., s. 22.1 .

Ibid. 
regime more in line with the European and American regimes, where the exemption from the stay is justified by reducing systemic risk to the derivative industry. ${ }^{90}$

The treatment of EFCs would not necessarily impact the orderly liquidation of a bank under the WURA. The provisions would only affect the EFC transactions in which the bank was a party to the contract. The GBI suggests that where insolvency set-off is recognized, it should not apply to the obligations of the bank or related parties. ${ }^{91}$ The 2007 amendments to the WURA do not include such a limitation. The reason for the GBI's proposal is to ensure that banks do not receive an unjustified advantage over outside creditors, over which there is great concern. In addition to the GBI's concern, it is important to highlight that these exceptions may also create implications for an orderly bank bankruptcy and the need to balance the risk to the derivative industry, with the wider systemic risk of a bank bankruptcy.

\section{(d) Realization and Distribution of Bank Assets}

The GBI highlights the importance of a clear and efficient system for bank's creditors to file claims and for reviewing such claims. Equally important is that the law clearly sets out the priority of different classes of claimants. The GBI recommends the following priority scheme for bank liquidations:

1. liquidators

2. employees

3. the crown

4. secured creditors

5. unsecured general creditors

6. the deposit insurance agency

7. subordinated bondholders

8. shareholders. ${ }^{92}$

The WURA does not provide a detailed scheme for the realization or the distribution of the bank's assets. The court is given wide discretion to set the claims process and timing, and to address objections to a liquidator's decision on claims. With the exception of the treatment of the Crown and employees, the priority of classes of claimants under the WURA largely follows the GBI recommendations.

Following the GBI's proposed scheme, the WURA provides that the charges, costs and expenses properly incurred in the winding-up of a company, including the

90 Stephanie Ben-Ishai \& Peter Kolla, "Derivatives and the CCAA" in Stephanie BenIshai \& Tony Duggan, eds. Canadian Bankruptcy and Insolvency Law: Bill C-55, Statute C.47 and Beyond (Toronto: LexisNexis Canada Inc., 2007). See also, Frank Partnoy \& David A. Skeel, Jr., "The Promise and Perils of Credit Derivatives" (2007) 75 U. Cin. L. Rev. at 1019, 1048-50; and Rhett G. Campbell, "Financial Markets Contracts and BAPCPA" (2005) 79 Am. Bankr. L.J. 697. 
remuneration of the liquidator, are to be paid in priority to all other claims against the company. 93

Generally, the claims of secured creditors rank ahead of the liquidator's charges, costs and expenses. ${ }^{94}$ However, courts have also recognized that the liquidator's costs in preserving and realizing assets may be entitled to priority over the claims of secured creditors if the costs incurred also benefit the secured creditors. ${ }^{95}$

Employees are given a vague priority under section 72 of the WURA which provides that "clerks or other persons in, or having been in the employment of, a company, in or about its business or trade, shall be collocated in the dividend sheet by special privilege over other creditors, for any arrears of salary or wages due and unpaid to them at the time of the making of a winding-up order in respect of the company, not exceeding the arrears that have accrued to them during the three months immediately preceding the date of that order." 96 This is a much more limited priority than what is available to employees under the Wage Earners Protection Program Act. ${ }^{97}$ Employee claims in a bank bankruptcy are a significant issue given that the large banks are major employers in Canada, employing over 250,000 people. ${ }^{98}$

The WURA does not specifically address Crown claims. Accordingly, the Crown retains the benefit of the priority conferred by a wide array of statutory liens, as well as its common law prerogative. The general Canadian policy, consistent with an international movement in this direction, has been to remove Crown priority in bankruptcy. 99 The main reasons for this include the recognition that the Crown is not a vulnerable involuntary creditor and to allow for more meaningful negotiation with the Crown in a bankruptcy. ${ }^{100}$ As a number of commentators have

93 WURA, supra, n. 22, s. 94.

94 Oriental Hotels Co., Re (1871), L.R. 12 Eq. 126 (Eng. Ch.) [Re Oriental Hotels Co.]; Regent's Canal Ironworks Co., Re (1875), 3 Ch. D. 411 (Eng. C.A.) [Re Regents Canal Ironworks Co.].

95 Re Oriental Hotels Co., ibid., at 132-33; Re Regent's Canal Ironworks Co., ibid., at 427.

96 WURA, supra, n. 22, s. 72.

97 Wage Earner Protection Program Act [Not in force], S.C. 2005, c. 47, s. 1. The WEPP provides compensation for unpaid non-management, non-related party employees who do not hold a controlling interest in the business of the former employer. Eligible employees will be able to apply for compensation from the WEPP for any unpaid wages or vacation pay earned during the six month period prior to the employer becoming bankrupt or being placed into receivership (but not severance or termination pay). The maximum amount of the compensation any employee will be entitled to receive is the greater of $\$ 3,000$ or four times the employee's maximum weekly insurable earnings under the Employment Insurance Act.

99 Stephanie Ben-Ishai, "Technically the King Can Do Wrong in Reorganizing Insolvent 100 Corporations: Evidence from Canada" (2004) 13 Int'l Insolv. Rev. at 115-36. 
pointed out over the years, there is no reason to depart from these justifications in the context of the WURA. ${ }^{101}$

The CDIC is not given a priority status under the WURA and, as is suggested by the GBI, depositors rank as unsecured creditors.

Under the WURA, secured creditors may elect to: (1) stand outside the liquidation proceedings and realize upon their security in any manner authorized by law; (2) release their security to the liquidator and prove their claim as an unsecured creditor; or (3) come into the liquidation proceedings, value their security, and prove their claim for any deficiency as an unsecured creditor. ${ }^{102}$

Pursuant to section 95 of the WURA, bondholders, followed by shareholders rank last in priority of distribution: "[T]he court shall distribute among the persons entitled thereto any surplus that remains after the satisfaction of the debts and liabilities of the company and the winding-up charges, costs and expenses, and unless otherwise provided by law or by the Act, charter or instrument of incorporation of the company, any property or assets remaining after the satisfaction shall be distributed among the members or shareholders according to their rights and interests in the company."103

\section{CONCLUSION}

Despite the small number of bank bankruptcies in Canadian history and the limited reforms to the WURA, this article has demonstrated that the Canadian bank bankruptcy regime generally fares well in an international context when assessed according to GBI benchmarks. To the extent that the WURA remains of limited use in liquidating banks in Canada, reform efforts would still be useful as the WURA will likely continue to serve as the framework for any informal negotiations or reorganizations in the face of a potential bank bankruptcy.

The WURA is clear on the role of the liquidator and the impact of the WURA proceeding on termination of banking activities. In order to allow for more meaningful stakeholder participation in a bank bankruptcy, greater clarity is needed on the role of parties other than the court and the liquidator. With respect to reviewable pre-bankruptcy transactions, clearer fraudulent preference provisions are needed to provide for certainty and the finality of transactions. Recent reforms to the application of the avoidance rules to EFCs provide a good model. In addition, the treatment of specific types of contracts, such as employment contracts should be clarified through legislation, as has been recently done in the context of the BIA and the CCAA. The provisions for a moratorium under the WURA are flexible, except with respect to EFCs, where the industry has pushed for greater certainty. Further tweaking with respect to the exception to the stay for EFC set-off rights where the bank is a party, should be considered. Finally, the distribution scheme found under the WURA generally conforms to international standards; however, the treatment of the Crown and employees should be revisited.

101 IIC, supra, n. 67 at 8; Telfer \& Welling, supra, n. 34 at 258-65. 